\title{
СУЧАСНА КЛІНІКО-ЕПІДЕМІОЛОГІЧНА ХАРАКТЕРИСТИКА БЕШИХИ НА ТЕРНОПІЛЬЩИНІ
}

\author{
Тернопільський державний медичний університет ім. І.Я. Горбачевського
}

Представлено дані власних клінічних спостережень і вивчення історій хвороб пацієнтів з бешихою, які в 2009-2014 рр. перебували на лікуванні в Тернопільській міській комунальній лікарні швидкої допомоги.

Ключові слова: бешиха, клінічні особливості.

На сьогодні бешиха залишається актуальною проблемою клінічної медицини, поступаючись в інфекційній патології лише грипу, вірусним гепатитам, кишковим інфрекціям та ВІЛ-іноекції [1].

Мета роботи - дати клініко-епідеміологічну характеристику бешихового запалення в Тернопільській області за останні шість років.

\section{Пацієнти і методи}

Представлені результати клінічних спостережень 240 хворих на бешиху, які лікувались в інсрекційному відділенні Тернопільської міської комунальної лікарні швидкої допомоги за шестирічний період (3 01.01. 2009 по 31.12.2014 рр.).

У роботі ми дотримувалися клінічної класифрікації бешихової інфрекції, яку запропонував В.Л. Черкасов (1986) [2].

\section{Результати досліджень та їх обговорення}

Річна динаміка захворюваності бешихою вказує на збільшення частоти ії реєстрації, з двома підйомами -у 2009 і 2012 рр.: у 2009 р - 50 хворих (20,8 \%), 2010 р. 31 (14,1 \%), 2011 p. - 39 (16,3\%), 2012 p. - 52 (21,7 \%), 2013 р. - $26(10,8 \%)$ і у 2014 р. - 39 пацієнтів (16,3\%).

За статевою ознакою спостерігається перевага жінок (136 хворих, 56,7 \%) над чоловіками (104 пацієнти, 43,3 \%), що збігається з даними авторів України та Росії, але не відповідає даним літератури з Болгарії, Швеції, Франції, Чехії, Ізраїля [2-4].

Вік пацієнтів коливається в широкому діапазоні - від 21 до 87 років, причому у чоловіків він вужче - від 21 до 78 років, а в жінок - від 25 до 87.

Спостерігається чітка сезонність: весною - 25 хворих, влітку - 37, восени - 169 і взимку - 9, тобто в літньоосінньому періоді бешихова інсрекція спостерігається більш ніж в чотири рази частіше (85,8 \%), порівняно із зімово-весняним (14,2 \%) (мал. 1).

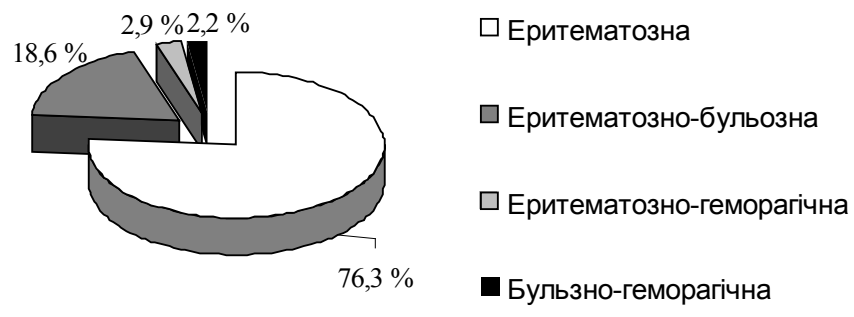

Мал. 1. Розподіл хворих за сезонністю бешихи (\%).

За кратністю захворювання розподіл спостережуваних пацієнтів такий: з первинною бешихою - 160 (66,7 \%), що значно переважає над іншими формами, рецидивна - 52 (21,7 \%) і повторна - 28 (11,6 \%).

Серед клінічних фоорм еритематозні форми (228 хворих, $95 \%$; еритематозна - 183 хворих і еритематозно-бульозна - 45 хворих) чисельно значно переважають над геморагічними (12 хворих, 5 \%; еритематозно-геморагічна -7 пацієнтів і бульозногеморагічна - 5 пацієнтів), що теж не збігається 3 даними авторів інших країн, які стверджують, що частота геморагічних фоорм хвороби збільшується і наздоганяє еритематозні [1, 2, 5], (мал. 2).

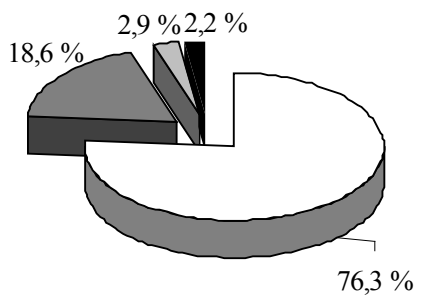

$$
\begin{aligned}
& \square \text { Еритематозна } \\
& \square \text { Еритематозно-бульозна } \\
& \square \text { Еритематозно-геморагічна } \\
& \square \text { Бульзно-геморагічна }
\end{aligned}
$$

Мал. 2. Співвідношення різних клінічних форм бешихового запалення (\%).

За тяжкістю спостерігається переважно середньотяжкий перебіг - 205 пацієнтів (85,4\%), легкий - у 6 $(2,5 \%)$ і тяжкий - у 29 (12,1 \%) осіб.

Локалізація інфрекційно-запального вогнища розподіляється таким чином: на нижній кінцівці - у 189 хворих (78,8 \%), на обличчі - у 45 (18,6 \%), в ділянці молочної залози - у $3(1,4 \%)$, на верхній кінцівці - у 2 $(0,8 \%)$ і на тулубі - в $1(0,4 \%)$. 


\section{ОРИГІНАЛЬНІ ДОСЛІДЖЕННЯ}

Загальний аналіз крові вказує на лейкоцитоз у 210 (87,5 \%) пацієнтів і збільшення ШОЕ - у 217 (90,4 \%) хворих на бешиху, відповідає даним літератури [6].

Прояви інтоксикаційного синдрому манісрестують такими симптомами: мерзлякуватість - у 216 (90\%) пацієнтів, гарячка - у 212 (88,3 \%), нальоти на язику -у 210 (87,5 \%), відчуття сухості в роті - у 206 (85,8 \%), біль у голові - у 200 (83,3 \%), адинамія - у 198 (82,5 \%), зниження або втрата апетиту - у 162 (67,5 \%), болі в м'язах - у 132 (55 \%), нудота - у 176 (73,3\%) та одноразова блювота - у 90 (37,5 \%).

Iз фронових (супутніх) захворювань бешихової інсрекції виявлено: ревмокардит - 1 (0,4 \%), отит $1(0,4 \%)$, варикоз вен нижніх кінцівок - 16 (6,7\%), виразка 12-палої кишки - 1 (0,4 \%), ішемічна хвороба серця - 36 (15\%), ожиріння II-III ступеня - 4 (1,7\%), хронічний панкреатит - 1 (0,4\%), артеріальна гіпертонія - 21 (8,8 \%), хронічний гепатит С - 5 (2,1\%), псоріаз 2 (0,8 \%), дерматит - 4 (1,7\%), пухлина - 2 (0,8 \%), мікоз стіп - 1 (0,4\%), оніхомікоз нижніх кінцівок - 3 (1,3\%), дерматофрітія - 1 (0,4\%), цукровий діабет II типу 15 (6,3 \%), гіпотиреоз - 1 (0,4\%), катаракта - $1(0,4 \%)$, цироз печінки - 3 (1,3\%), трофрічна виразка ніжньої кінцівки - 1 (0,4\%), мікробна екзема нижніх кінцівок - 1 (0,4 \%), посттромбофлебітний синдром - 1 (0,4 \%), хронічний гастродуоденіт - 1 (0,4 \%).

Ускладнення (тільки локальні) встановлено у 20 з 240 хворих на бешихове запалення, а саме: фрормування слоновості нижньої кінцівки - у 18 (7,5 \%) пацієнтів і абсцедування - у 2 (0,8 \%), що теж відповідає даним літератури [7-10].

\section{Висновки}

1. Бешихова інфекція спостерігається частіше у жінок.

2. Еритематозні фрорми хвороби значно превалюють над геморагічними.

3. Середньотяжкий перебіг бешихи зустрічається частіше, ніж легкий і тяжкий.

4. Основна локалізація інфекційно-запального процесу - нижні кінцівки.

5. Серед фонових захворювань найчастіше виявлено ішемічну хворобу серця, артеріальну гіпертонію і цукровий діабет II типу.
6. Ускладнення розвиваються відносно рідко, причому тільки локальні.

\section{Література}

1. Оспанбекова Н.К. Рожа. Дифрференциальная диагностика / Н.К. Оспанбекова. - Альматы: Изд-во КНМУ, 2014. - 94 с. C. 9 .

2. Черкасов В.Л. Рожа / В.Л. Черкасов. - Л.: Медицина, 1986 -200 c. - С. $65-68$.

3. Ніколов В.В. Сучасна клініко-епідеміологічна характеристика бешихи в Болгарії / В.В. Ніколов // Інфекційні хвороби. - 2014. № 4 (78). - С. 42-44.

4. Покровский В.И. Стрептококки и стрептококкозы / В.И. Покровский, Н.И. Брико, Л.А. Ряпис. - М.: ГЭОТАР-Медия, 2006. $-544 \mathrm{c}$

5. Analysis of epidemiology, clinical features and management of erysipelas / [K. Krasagakis, A. Valachis, P. Maniatakis et al.] // Int. J. Dermatol. - 2010. - Vol. 49, N 9. - P. 1012-1017

6. Юнгарева И.Х. С-реактивен протеин и СУЕ - прогностични маркери при еризипела / И.Х. Юнгарева, В.В. Николов, С.С. Марина // Дерматология и венерология. - 2012. - № 1. - С. 52-56.

7. Клінічні та епідеміологічні особливості сучасної бешихи / Н.І. Ільїна, М.Д. Чемич, В.В. Захлєбаєва, Н.О. Капустян // Інсрекційні хвороби. - 2014. - № 4 (78). - С. 39-42.

8. Оспанбекова Н.К. Рожа. Основные подходы к диагностике и лечению / Н.К. Оспанбекова // Здоровье Казахстана. - 2014. № 2 (22). - C. 14-15.

9. Local complications of erysipelas: a study of associated risk factors [K. Krasagakis, G. Samonis, A. Valachis et al.] // Clin. Exp. Dermatol. - 2011. - Vol. 36 N 4. - P. 351-354.

10. Davis L. Erysipelas / L. Davis, J.A. Cole, K. Benbenisty // Lancet. - 2010. - Vol. 378. - P. 1682-1701.

\section{CLINICAL AND EPIDEMIOLOGICAL CHARACTERISTICS OF ERYSIPELAS IN TERNOPIL REGION}

V.V. Nikolov

SUMMARY. The data own clinical observations and studies the case histories of patients with erysipelas for the six year period (from 01.01.2009 by 31.12.2014), who were treated in the Ternopil city Municipal Hospital Emergency.

Key words: erysipelas, clinical features.

Отримано 28.02.2015 p. 